\title{
Maintaining Biodiversity in Freshwater Ecosystems on O- ceanic Islands of the Tropical Pacific
}

\author{
FITZSIMONS J. MICHAEL \\ Louisiana State University Museum of Natural Science; Baton Rouge, Louisiana 70803 USA \\ NISHIMOTO ROBERT T. \\ Hawai'i Division of Aquatic Resources, 75 Aupuni Street, Hilo, Hawai'i 96720 USA \\ DEVICK WILLIAM S. \\ Hareai'i Division of Aquatic Resources, 1151 Punchbowl Street Honolulu, Hawai'i 96813 USA \\ (Received September 26, 1995)
}

\section{ABSTRACT}

\begin{abstract}
Stream animals on tropical high islands have ecological counterparts among continental fauna but are confronted with highly dynamic and variable environmental conditions that can far exceed those occurring in mainland streams. In response to weather fronts passing through an island chain or to localized fluctuations in the formation of orographic rain, water levels in island streams can change from low flows of a few centimeters depth to sudden flash floods of several meters and back to clear shallow water within a few days. Studies of the five species of indigenous Hawaiian stream fishes have shown that the dispersal of larvae out to sea and their return several months later during their amphidromous life cycles constantly restock streams and provide a kind of ready reserve for recolonizing streams after unusually harsh disturbances, such as the recent Hurricane Iniki. Because of the predominance of amphidromy among the major species of stream fishes and macroinvertebrates on tropical Pacific high islands, we hypothesize that maintaining biodiversity in these island streams when conditions are otherwise favorable and restoring animal life to formerly diverted streams may be no more complicated than assuring that the freshwater-marine threshold remains open and that natural fluctuations in flow are unhampered.
\end{abstract}

Key words amphidromy, freshwater ecosystems, stream restoration, gobioid fishes

During the past five years, a research group from the Hawai'i Division of Aquatic Resources and the Louisiana Stae University Museum of Natural Science has collaborated on a series of studies concerning the biology and conservaion of stream animals in the Hawaiian Islands. From the viewpoints of both geology and biology, these islands represent the northernmost extenson of Polynesia. Stream animals in Hawai' $i$ have relatives at the level of family, genus, and occasionally even species not only in Polynesia but throughout Melanesia and Micronesia as well. For this reason, we hypothesize that the major discoveries regarding Hawaiian stream animals will be relevant to aquatic fauna throughout the oceanic high islands of the tropical Pacific. This report, based on a talk presented during the Symposium on the Structure and Function of Biodiversity in Pacific Ecosystems at the 18th Pacific Science Congress in Beijing, June 1995, is intended to spur interest in biological studies and monitoring of stream animals throughout the tropical Pacific in keeping with the long-term goals of the Pacific Science Association's Committee on Ecology, Conservaion, and Environmental Protection (Dr. Dieter Mueller-Dombois, Chairperson). The authors are eager to share 
reprints, manuscripts, and correspondence with individuals interested in initiating biodiversity studies in streams among other groups of Pacific islands.

Biodiversity in stream ecosystems on tropical oceanic islands can be influenced by many natural conditions or events, but perhaps five stand foremost. These include the relative isolation of an island or archipelago, its geologic stage of development, prevailing weather patterns, tropical storms, and the life cycles of indigenous animals.

\section{Isolation}

It is axiomatic that the relative isolaion of a group of islands will determine the variety of animal and plant life that occurs there naturally. In general, extreme isolation results in a reduction of the number of species and an increased fraction of species that are endemic. These two effects are especially conspicuous among fishes of the Hawaiian Archipelago whose southeastern hi ${ }^{\cdot}$ islands are unequaled in their isolation. The fish fauna of Hawai' $i$ includes about 400 species, and, while this number may seem sizable, three to four times that many species occur elsewhere in the tropics of the Western Pacific Ocean. Fully one-third of Hawaiian fishes are endemic, i.e., they occur nowhere else in the world.

The freshwater fishes include only five species: Eleotris sandwicensis ('o'opu akupa), Stenogobius hawaiiensis ('o' opu naniha), Awaous guamensis ('o'opu nakea), Sicyopterus stimpsoni ('o'opu nopili), and Lentipes concolor ('o'opu alamo'o). All five species are indigenous (native), and four are endemic. These fishes, collectively referred to as gobioids (from the subordinal name Gobioidei) are included in two families. The family Eleotridae (sometimes Eleotrididae) includes species like 'o' opu akupa that have separate (unfused) pelvic fins; members of the Gobiidae have fused pelvic fins that function like a suction cup with which the animals attach to rocks in swift water. The larger invertebrates (macroinvertebrates) of Hawaiian streams include three species of crustaceans and two species of mollusks. The shrimp Atya bisulcata ('opae kuahiwi) and prawn Macrobrachium grandimanus ('opae oeha'a) are indigenous species restricted to Hawai' $i$; Macrobrachium lar (the Tahitian or Guamanian prawn) was introduced into Hawai' $i$ in 1956 (Pelekunu Stream, Moloka' $i$ ) and on several occasions during 1957 1961 ( $\mathrm{O}^{\prime} \mathrm{ahu}$ ). Neritina granosa (hihiwai, wi, or river opihi) and Theodoxus vespertinus (hapawai) are patelliform mollusks known only from Hawaiian fresh waters.

\section{Geologic stage}

The stage of development of an island or island group will determine whether streams are available for aquatic animals. High islands of the Pacific are volcanic in origin and are formed one-by-one as the ocean floor moves over a hot spot from which island-building lava is extruded. When an island extends 2000 to 4000 feet or more above the surface of the sea, conditions become favorable for the formation of freshwater streams as moisture in trade winds condenses in the cooler air at these elevations to form rain on windward mountain slopes.

\section{Prevailing weather patterns}

Well established freshwater communities occur in streams that flow continuously throughout the year on the windward sides of islands where orographic rain is a characteristic 
climatic feature. In contrast, intermittent streams are most common in the rain shadow on the leeward sides of islands. Produced by the rotation of the earth, tradewinds and associated rainfall over Pacific islands are persistent but seldom constant. Strong fronts approaching from leeward can halt the normal flow of trades for a few days to several weeks, and localized storms can produce heavy rainfall on the leeward sides of islands. These weather conditions, even if of relatively short duration, can bring about a temporary surge in growth of vegetation (predominantly grasses and shrubs) in formerly dry areas and cause intermittent streams to flow into the ocean. In Hawai' $i$, the usually short-term reversals of wet vs dry sides of islands are often associated with "kona storms" during winter months. A similar trend occurs in many island groups to the far south and west of Hawai' $i$ although the proximity of continents or even other large islands can have a moderating influence on the fluctuation of prevailing winds and rainfall. In addition, the differential heating of the sea surface attributable to El Niño has been implicated recently in disrupting the normal flow of tradewinds in the Hawaiian Islands and elsewhere.

Flash floods or freshets generated by episodic storms have been an important part of the evolutionary history of stream animals on oceanic islands in the tropics. Frontal passages resulting in localized rainfall of only one or two inches in an hour may produce a freshet capable of overflowing a stream's banks, rearranging its bottom, and unplugging its mouth by washing debris, loose sand, gravel, and rubble out to sea. Once the rains ease, a return to preflood conditions in mountain streams may occur in as few as two or three days. Although such dramatic fluctuations in water level and stream velocity may appear severe from the perspective of stream ecology on continents, they actually are essential for freshwater animals living on islands. In high-gradient streams, occasional flash floods flush away accumulations of organic debris and sediments, terminate algal blooms, and open up the stream where it flows into the sea to permit easier access for young animals recruiting into fresh water (see below). Preliminary studies indicate that freshets may be important also in sending olfactory or gustatory signals into nearshore waters that attract larval animals which leave the sea and spend their adult lives in streams. "Healthy" stream environments on oceanic islands, then, can best be described as dynamic. The concept of stability through the maintenance of a some minimum year-round base flow as frequently proposed for continental streams is a harmful rather than useful approach to stream management in Hawai' $i$ and in other comparable islands of the tropical Pacific.

\section{Tropical storms}

Susceptibility to powerful cyclones (typhoons or hurricanes) varies throughout the tropics, but these storms remain a potential threat to all South Pacific islands.

Hurricane Iniki (September 11, 1992) was the most powerful storm on record to have reached the Hawaiian Islands. With sustained winds of $234 \mathrm{~km} / \mathrm{h}$ and localized pockets of wind exceeding $300 \mathrm{~km} / \mathrm{h}$ (Fujita 1993), this Category-4 hurricane severely damaged terrestrial habitats all over the island of Kaua' $i$ (Fitzsimons and Nishimoto 1993). Hurricane winds alone probably had little effect on aquatic habitats. However, a flash flood about four weeks later moved hurricane debris, including entire trees and large amounts of rock, sand, and gravel downstream with such terrific force that the stream bed in Hanakapi' ai Valley was scoured and leveled (Fitzsimons and Nishimoto 1995). Habitats for two species of fishes (Awaous guamensis and Sicyopterus stimpsoni) common in midstream reaches were obliter- 
ated, and two other species (Stenogobius hawaiiensis and Eleotris sandwicensis) characteristic of the lower sections of streams were missing and probably pushed out to sea. Sicyopterus stimpsoni was crowded downstream in such large numbers that injurious aggressive interactions among these fish all but curtailed feeding and completely eliminated usual reproductive behavior. Only Lentipes concolor, famous for its abilities to climb sheer waterfalls of more than $100 \mathrm{~m}$, was not displaced downstream, but the permanent territories of adult males were still being reestablished a month after the storm (a week after the flood). Other streams were affected less severely. The wide channel and lower stream gradient of Wainiha River dissipated the energy of the flood, and, $\mathrm{Nu}^{\prime}$ alolo Stream, not reached by the flash flood, was protected from strong winds throughout most of its length by high valley walls. Concomitantly, animals in these latter streams showed less deviation from typical instream distribution and behavior.

Hurricane and flood damage appeared to affect both terrestrial and aquatic habitats in Hanakapi'ai Valley equally severely, yet within about a year after Hurricane Iniki, discrete stream habitats had reappeared and an expected complement of native fishes and macroinvertebrates exhibited nearly typical distributions, densities, and behavior. In contrast, many years will be essential for the complete return of riparian plants and especially for the regrowth of trees througout stream valleys. At the end of the 20 -month study, researchers concluded that under natural conditions tropical storms do not cause irreversible damage to Hawaiian streams. The remarkably quick recovery of Kaua'i streams was believed to have been enhanced by each species' adaptations for surviving in swift water and by the amphidromous life cycle characteristic of every species of freshwater fish and macroinvertebrate that occurs naturally in Hawaiian streams.

\section{Life cycles}

The major species of stream animals in Hawai' $i$ are amphidromous (Tate et al. 1992). Adults lay their eggs in freshwater, and there are two migrations: one when the newly hatched animals are swept downstream into the ocean, and the second one when, still in a larval or early postlarval condition, they return to freshwater after living in the ocean for several months. The recruitment of fishes and macroinvertebrates into hurricane-damaged streams on Kaua'i was not affected by Hurricane Iniki. Patterns of recruitment into streams on Kaua $i$ over the 20 -month period of study were very similar to those observed for streams on the island of Hawai' $i$ some $460 \mathrm{~km}$ from kaua' $i$ where there were no detectable hurricane effects on aquatic communities. The tendency of larval and postlarval stream fishes and macroinvertebrates to orient shoreward and to move into the mouths of streams is sufficiently strong and imperative that -we concluded even the most heavily storm-damaged streams are self-repairing under certain circumstances. Rapid recovery of a stream has three requirements: First, conditions must have been otherwise favorable for aquatic animals before the disturbance. Second, access must be readily available for young animals moving into the stream from the ocean, and, finally, natural fluctuations in flow, including freshets, must be unimpeded.

\section{Significance of amphidromy to stream restoration and preservation}

In addition to the recruitment of larval fishes and invertebrates into Kaua'i streams after Hurricane Iniki, other examples of the remarkable colonizing ability of gobioid stream fishes 
and invertebrates include the movement of young animals into leeward intermittent streams when flow is temporarily reestablished, their entrance into artificial streams where water taken from a stream is eventually allowed to flow back into it (Wailoa Fishery Research Station, Division of Aquatio Resources, Hilo), and their rapid recruitment into a windward stream whose flow was partially restored after decades of diversion for agriculture.

An amphidromous life cycle, characteristic of all 10 species of fishes and macroinvertebrates living in Hawaiian mountain streams, is a requirement also for most of the larger aquatic animals living in fresh waters throughout oceanic high islands of the South Pacific Ocean. The marine larval phases of these animals provide stocks for sustaining populations in island freshwater ecosystems and for recolonizing streams damaged by storms and other natural disasters.

This paper has singled out for discussion only a few of the natural conditions that can affect biodiversity in streams on tropical Pacific high islands. In truth, the activities of humans have a far greater effect. A single islander who diverts a stream or allows pollutants to enter a stream can produce an impact potentially more damaging and permanent than even a major hurricane. Fortunately, the biological attributes of the animals themselves provide the best means of effecting stream restoration and preservation, and here again a sharp distinction between streams on islands vs those on continents is evident. The return of a continental stream to a near-original condition usually requires restocking of hatchery-reared fishes. On oceanic islands where amphidromous stream animals are predominant, restocking will occur without assistance once a stream is put back into a condition favorable for aquatic animals and allowed unimpeded flow into the ocean.

Amphidromy provides a kind of "natural insurance against extinction" for aquatic animals in island streams, but that insurance remains in force only if damage to a stream is reversible and only if there is protection for high quality streams that provide the marine larvae essential to recolonization. Viewed more broadly, it is these larvae that are absolutely essential to sustaining species and maintaining biodiversity in freshwater communities on oceanic islands throughout the South Pacific. We believe that any program of stream refurbishment and conservation on tropical Pacific islands must focus first on a single pervasive concept-amphidromy.

\section{REFERENCES}

Fitzsimons J M, R T Nishimoto, 1993. Initial assessment of the impact of Hurricane 'Iniki on Stream Ecosystems on the Island of Kaua' $\mathrm{i}$. In: W S Devick (ed. ), Assessments of the impact of Hurricane 'Iniki on stream biota and ecosystems on Kauai, Hawai' $i$ Department of Land and Natural Resources, Division of Aquaic Resources, Honolulu, 4 45

Fitzsimons J M, R T Nishimoto, 1995. Use of fish behavior in assessing the effects of Hurricane 'Iniki on the Hawaiian island of Kaua'i. Environ. Biol. Fishes, 43:39 50

Fujita T T, 1993. Damage map of Hurricane' Iniki. NOAN/National Weather Service (40AANW204612), Office of Naval Research (N000014-91-J1136), University of Chicago (2-64613), 1

Tate D C, J M Fitzsimons, R P Cody, 1992. Hawaiian freshwater fishes (Osteichthyes, Gobioidei) : A field key to the species of larvae and postlarvae during recruitment into fresh waters. Occ. Paps. Mus. Nat. Sci., $65: 1 \sim 10$ 